\title{
A Review of Edward Flatau's 1894 Atlas of the Human Brain by the Neurologist Sigmund Freud
}

\author{
Lazaros C. Triarhou \\ University of Macedonia, Thessaloniki, Greece
}

\section{Key Words}

Human nervous system • Edward Flatau • Sigmund Freud • Gustaf Retzius • Brain atlas • History of neuroanatomy • Neuron theory

\begin{abstract}
In 1894, the Polish neurologist Edward Flatau (1868-1932), working in Berlin, published an exquisite photographic atlas of the unfixed human brain, preceding by 2 years Das Menschenhirn, the reference work of Gustaf Retzius (1842-1919) in Stockholm. In his early career as a neuroanatomist and neurologist, Sigmund Freud (1856-1939) wrote a review of Flatau's atlas for the Internationale klinische Rundschau, which has not been included in the 'Standard Edition of the Complete Psychological Works'. The aim of the present paper is twofold: to document Freud's review, and to revive the largely forgotten atlas of Flatau. The full text of Freud is presented in translation. Further, one element Flatau, Retzius and Freud had in common is discussed: their early role as protagonists and firm supporters of Ramón y Cajal's neuron theory, the cornerstone of modern neuroscience.
\end{abstract}

Copyright $\odot 2010$ S. Karger AG, Basel
(C) 2010 S. Karger AG, Basel

0014-3022/11/0651-0010\$38.00/0

Fax +41613061234 E-Mail karger@karger.ch www.karger.com

\section{Introduction}

The paths of Edward Flatau (1868-1932), the founder of Polish neurology, and Sigmund Freud (1856-1939), the acknowledged father of psychoanalysis, crossed in 1897 , while they were both serving on the editorial board of Karger's Jahresbericht über die Leistungen und Fortschritte auf dem Gebiete von Neurologie und Psychiatrie ('Annual Report on the Accomplishments and Progress in the Fields of Neurology and Psychiatry'). The general editor of that journal was Emanuel Mendel (1839-1907); the editorial board comprised such eminent brain researchers as Vladimir Bekhterev (1857-1927), Max Bielschowsky (1869-1940), Ludwig Jacobsohn (1863-1941), Siegfried Kalischer (1862-1954), Lazar Minor (1855-1942), Heinrich Obersteiner (1847-1922), Arnold Pick (1851-1924), Bernhard Pollack (1865-1928) and Theodor Ziehen (1862-1950) [1].

From his student years, in the late 1870 s, through the 1890 s, Freud occupied himself with the histology, anatomy and pathology of the nervous system, before permanently switching to psychology [2]. In 1891, he published his Critical Study on Aphasia, a neurology classic [3]. During those 'neurological' years, Freud regularly reviewed neuropsychiatric articles and books for medical journals. Two such reviews concern anatomical works,

Lazaros C. Triarhou, MD, PhD

Professor of Neuroscience, University of Macedonia

Egnatia 156, Bldg. Z-312

GR-54006 Thessaloniki (Greece)

Tel. +30 2310891 387, Fax +30 2310891 388, E-Mail triarhou@ uom.gr 


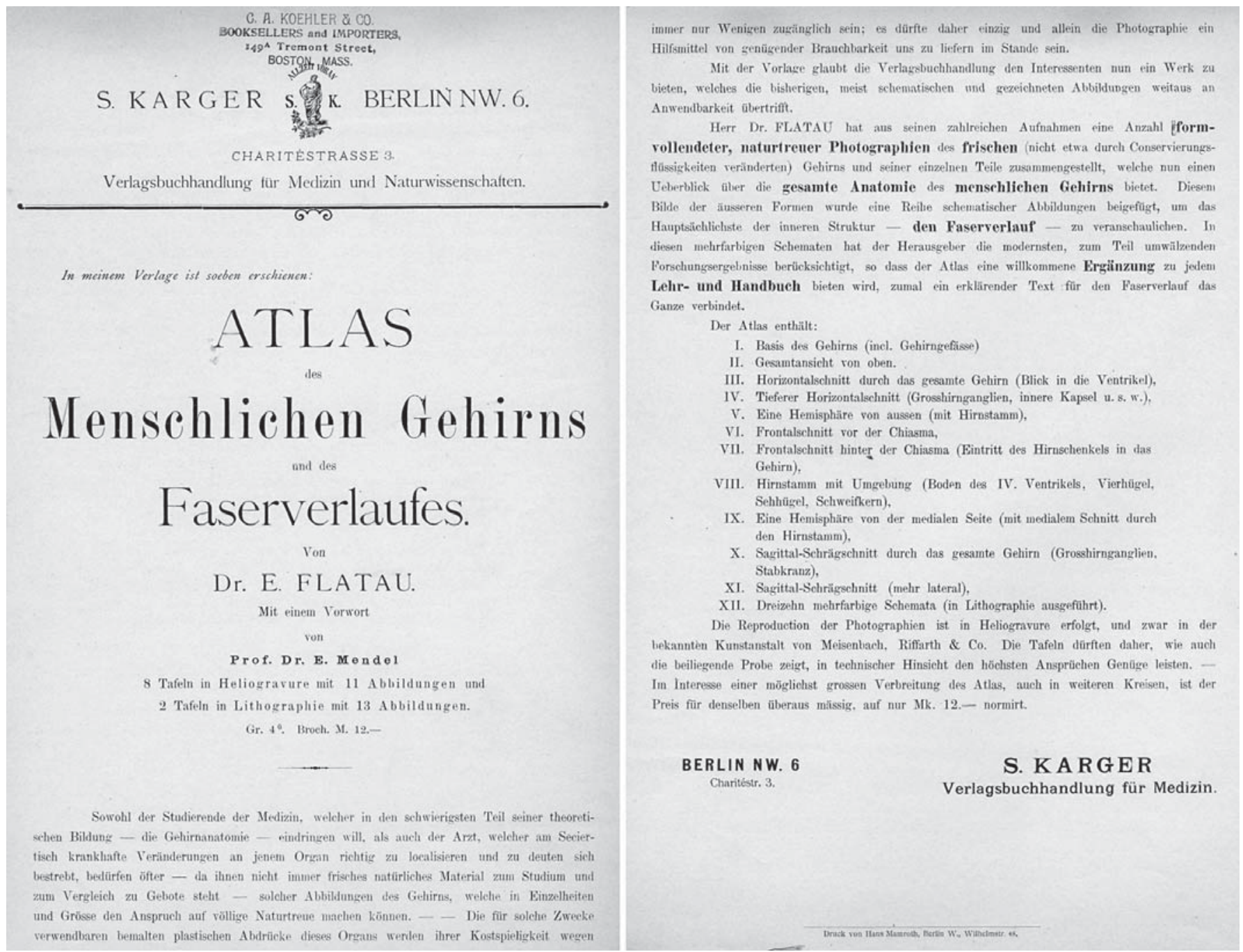

Fig. 1. A kit by the Samuel Karger Verlag in Berlin for the promotion of Flatau's 1894 Atlas of the Human Brain (author's archive).

namely, Obersteiner's textbook on the central nervous system [4], and Flatau's atlas of the human brain [5]. These two reviews have not been included in the Standard Edition of the Complete Psychological Works [6]. They are listed as works '1887e' and '1894b', respectively, in the Ausgewählte Bibliographie by the Freud Museum in Vienna (http://www.freud-museum.at/cms/online/ freud/themen/biblio.htm).

Flatau was born in Płock, Poland. He graduated from Moscow University in 1892 and worked in Berlin between 1893 and 1899, the year he returned to Warsaw [7, 8]. In 1894, at the age of 26 years, Flatau published his Atlas of the Human Brain and the Course of Nerve Fibres [9]. That work (fig. 1), in large quarto $(27 \times 36 \mathrm{~cm})$, most likely rep- resents the first photographic atlas of the human brain in the German language. It appeared in print 2 years prior to the publication in Stockholm of the photographic atlas Das Menschenhirn by Gustaf Retzius (1842-1919), perhaps the most outstanding work in macroscopic neuroanatomy of the 19th century [10].

Flatau used whole and dissected human brains, unfixed and only rinsed in water. He applied small diaphragms to effect a better depth of field, and took longexposure photographs, with exposure times of 20-30 min for uneven surfaces (ventral, dorsal, lateral and medial facies, plates I, II, V and VII), and up to $10 \mathrm{~min}$ for flat sections (horizontal, coronal and sagittal, plates III/ IV, VI and VIII) $[9,11]$ (fig. 2). A schematic color chro- 
Fig. 2. A sample plate (Probetafel) from Flatau's Atlas of the Human Brain by Karger, Berlin, left, depicting the ventral cerebral facies (author's archive). Flatau demonstrating his method for macroscopically photographing fresh human brains, right; from a technical article [11] traced from a citation by Pollack [51] (courtesy: Universitätsbibliothek Hamburg).
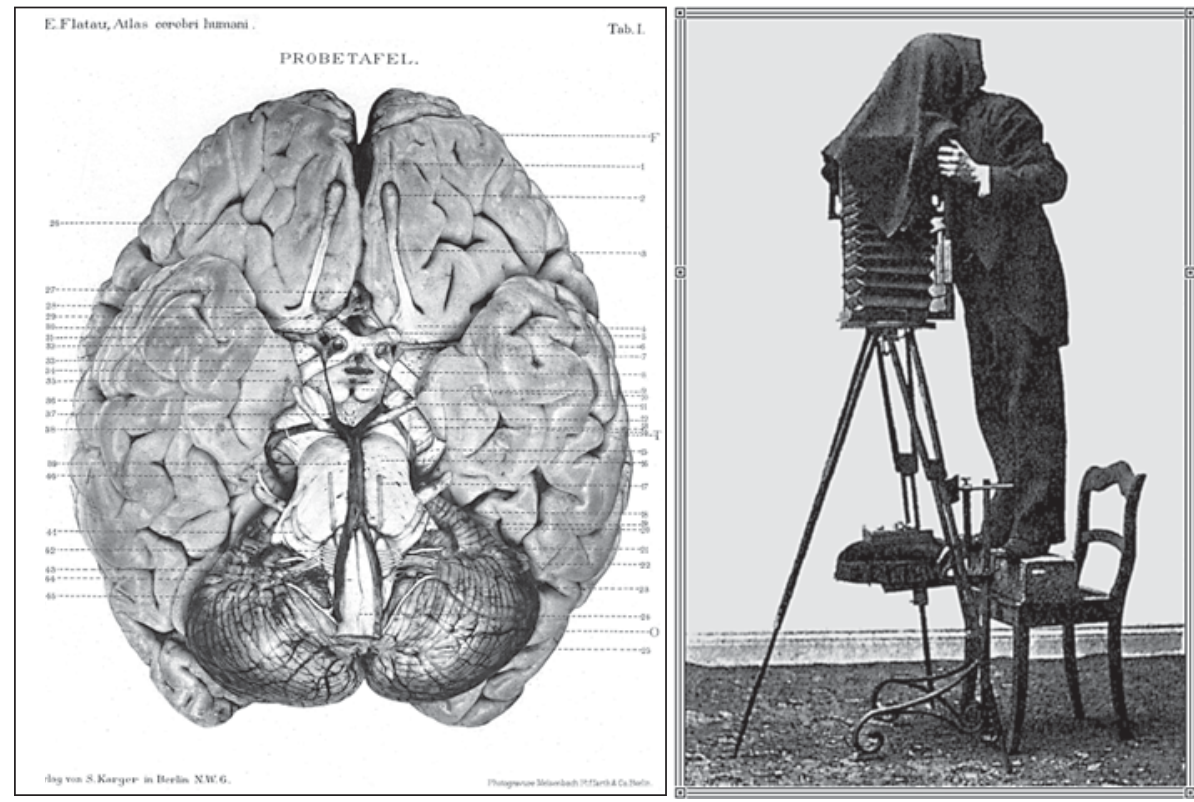

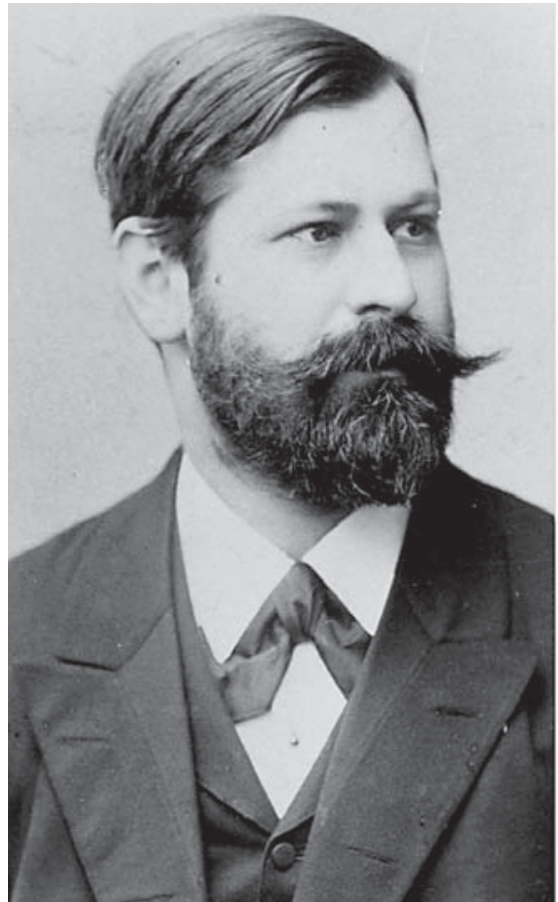

Internationale Klinische Rundschau $1894 . \quad 113$

Kritische Besprechungen und literarische Anzeigen

\section{Atlas}

\section{des menschlichen Gehirns und des Faserverlaufes.} Yon Ed. Flatau.

Mit einem Vorwort ron Prof. E. Mindel. Verlag von S. K a r g e r. Berlin $189 !$

Dr. Furav bietet hier Aerzten und Studirenden einen Allas des menseblichen Gehirns, welcher auf 8 Tafeln (11 Abbildungen) die verschiedenen Gesammtansichten und einige der wichtigsten Gebirndurchschnitte darstellt. Diese Tafeln - nach Photographien des frischen Gehirns - geben von den Gehirnoberflalchen einen geredezu plastischen Bindruck, sind in den Durchschnitten klar und charakteristisch und verdienen in ihrer Gesammtheit als ein vorzügliches Lehrmittel bezeichnet $\mathrm{zu}$ werden, dessen man sich beim Selbststudium im Falle von Mangel an frischem Material, zum Vergleiche bei Autopsie und dergleichen mit vollem Vertrauen bedienen darf.

Eine diesem Atlas vorangestellte sschematische Tafel, versucht in 13 mehrfarbigen Figuren eine Uebersicht unserer Kenntnises rom Verlaufe der Faserbahnen im Centralnervensyslem zu seben, die sich an die bekannten Bearbeitungen dieses Themas von Mendzr, Bechrgrw und Episagr anlehnt und auf die durch GoLat und RAMON verănderten Ansichten über die Structur des Nervengewebes aufgebant ist. 27 Seiten Text sind der Brklärung dieser schematischen Bilder gewidmet. Der Preis des Werkes (12 Mark) ist hei der Fülle und Schönheit des Gebotenen geringrägig zu heissen. Herausgeber und Verleger verdienen den Dank des ärzllichen Publikums für dieses werthvolle Werk. SFC.

Fig. 3. The 35-year-old Sigmund Freud in Vienna, left (credit: Sigmund Freud Museum, London). Freud's review [5] of the Flatau atlas, middle (courtesy: Universitätsbibliothek der Medizinischen Universität Wien). The 33-year-old Edward Flatau in Berlin, right (credit: Wikimedia Commons, http://upload.wikimedia.org; original photograph traced by Eisenberg [18] in the Berta Lask Archive, Berlin Academy of Arts). 
molithograph depicted central brain pathways and connections $[9,12]$.

The work had been carried out in the laboratory of the Neuropsychiatric Institute of Emanuel Mendel, who also contributed the preface. The atlas was simultaneously published in German, English, French, Polish and Russian $[9,12]$. A supplement on microscopy [1] and an inclusive second, revised and enlarged edition [13] were issued 5 years later, including seven additional plates (IX$\mathrm{XV}$ ) depicting the cranial nerve nuclei, midbrain, pons, medulla, and spinal cord. Flatau incorporated his 1897 discovery - known as Flatau's law - that the greater the length of a fiber in the spinal cord, the more eccentrically it is located [14], as well as key findings from his degeneration studies [13]. The supplemental work for the second edition was carried out at the Anatomical Institute of Wilhelm Waldeyer (1836-1921).

With Jacobsohn, Flatau co-authored another classic, the Handbook of Comparative Anatomy of the Mammalian Central Nervous System [15]. With Minor, they coedited a two-volume Handbook of Neuropathology [16, 17]. Both texts became indispensable references for their contemporaries and successors $[18,19]$.

An English translation of Freud's review [5] follows (fig. 3). The review of Obersteiner's textbook [4] forms the subject of a separate paper.

\section{The Review by Freud}

Dr. Flatau hereby offers physicians and students an atlas of the human brain, which depicts the various full views and some of the most important brain sections in eight plates (11 figures). These plates - from photographs of fresh brain - give an almost threedimensional impression of the cerebral facies, in clear and characteristic sections, overall deserving to be designated as a superb teaching aid, suitable as a totally reliable reference for both selfstudy, in the case of not having access to fresh material, and for comparisons at autopsy and the like.

A leading 'schematic plate' in this atlas attempts to give an overview of our knowledge on the course of fiber pathways in the central nervous system in 13 multi-colored drawings, incorporating the known accounts of Mendel, Bekhterev and Edinger on this theme, and continuing with the opposing views of Golgi and Ramón [y Cajal] on the structure of the nervous tissue. The 27 text pages are devoted to the explanation of these schematic drawings. The price of the work (12 marks) is minimal if one considers its breadth and beauty. Author and publisher deserve the appreciation of the medical community for this valuable work.

Sigmund Freud

[Atlas of the Human Brain and the Course of Nerve Fibres. By Ed. Flatau. With a Foreword by Prof. E. Mendel. S. Karger Verlag, Berlin 1894. (Critical Reviews and Literary Notices.)]

Freud on Flatau's Atlas

\section{Comment}

\section{Photographic versus Drawn Atlases of the Human \\ Brain}

The Iconographie Photographique [20] by the French neurologist Jules Bernard Luys (1828-1897) constitutes the first photographic atlas of the human brain. Prior to that artistic drawings were used to depict brain structure in standard atlases of the time [21-24]. The advent of the photographic technique, with its acclaimed precision, would eventually secure more impartial, impersonal and authentic reproductions of brain form, deemed by investigators to be more accurate than drawings and engravings [25]. In the words of Koskinas [26], '...the hitherto investigations of the brain depicted things schematically and therefore subjectively; if one aims at representing specimens accurately, one makes use of photography; photographic documentation constitutes the most truthful testimony of an exact depiction of nature, as it provides a truly objective image of things as these bear in natural form, size and arrangement.'

The industrious Luys ('subthalamic nucleus of Luys') developed an original view of the structural and functional organization of the brain, and contributed to our knowledge of the neuropathological aspects of mental illness [27]. The Iconographie [20] was illustrated with 70 plates containing 81 original albumen prints of brain sections (fixed in a chromate-glycerin solution), plus schematic drawings from his hand.

Édouard Brissaud (1852-1909; upturned 'sulcus of Brissaud' on the superolateral convexity of the superior parietal area) authored the Anatomie du cerveau de l'homme accompanied by a splendid atlas with 43 plates [22], drawn by himself in what appears to be a fine art; that prodigious work is still relevant today [28].

The pinnacle of photographic brain atlases of the late 19 th century is considered to be the 167-page text volume and the 96 -collotype plate volume in large quarto $(30 \times 39$ $\mathrm{cm}$ ) of Retzius [10]. The massive opus of scholarship was issued in a limited run of 500 sets. The text was organized in three parts, dealing with the development of the human brain, the morphology of the human brain, and the surface pattern of cortical sulci and gyri in 100 adult hemispheres (35 male right, 40 male left, 12 female right, and 13 female left). The plates comprised 486 drawings (by Sigrid Andersson, Hilma Bundsen, Gustaf Wennman and Ebba Flodman) and 327 directly reproduced photolithographs in natural size; about one third of the plates covered prenatal development (2-9 months of gestation), and the remaining two thirds depicted the adult macroscopic 
brain structure, with emphasis on individual variations. Specimens were fixed in chrome-osmium-acetic acid, potassium bichromate or formalin. Retzius clarified some of the more difficult problems of cerebral morphology. The wealth of the illustrations and their detailed description rendered Das Menschenhirn the best work ever offered until then [29], and also addressed age and gender differences. Retzius made some new discoveries, such as the saccular eminence on the tuber cinereum, the homologue of the saccus vasculosus of lower vertebrates, the relations of the amygdala, and new gyri in the rhinencephalon, the gyrus ambiens and semilunaris, and the fasciolar gyrus. He paid homage to his late father, anatomy professor Anders Retzius (1796-1860) of Karolinska Institutet, by dedicating Das Menschenhirn in commemoration of the latter's 100 th birthday, and by naming the rudimentary intralimbic gyri after him ('gyri of Anders Retzius').

\section{Freud, Neurology and the Neuron Doctrine}

Freud made substantial contributions to basic neuroscience and clinical neurology [2, 30, 31]. He carried out pioneering neuroanatomical studies, using the Weigert method, on the connections of the superior olivary nuclei, on the origin and course of the eighth cranial nerve, and on the relations of the restiform body, as well as neuropathological studies on acute polyneuritis, aphasia, and infantile cerebral diplegia. He suggested, decades ahead of his time, that the trigeminal nucleus might be involved in migraine, also ascribing an important role to the meninges and the innervation of blood vessels [30]. With his histological studies on the spinal ganglia and spinal cord of the lamprey and the structure of nerve cells and fibers in the river crayfish, Freud became one of the early protagonists of the neuron theory $[2,32,33]$. He demonstrated the fibrillary structure of the protoplasm and docu-

'neuron' (Greek $v \varepsilon v \tilde{v} \rho o v=$ nerve) first appears in Homer [38]. Waldeyer [37] adopted the term 'neuron' (Greek $\nu \varepsilon v \rho \omega \dot{v}=$ nerve cell) and popularized the neuron theory, largely based on the landmark discoveries of Ramón y Cajal [39-41], and the substantial contributions of Forel, van Gehuchten, Gowers, His, Kölliker, von Lenhossék, Nansen, Nissl, and others [33, 36, 42-44]. Studying a wide variety of invertebrate and vertebrate species, Retzius had also provided evidence that helped establish the neuron theory $[45,46]$.

In the first paragraph of his atlas, Flatau states: 'The function of the dendrons is not as yet positively known, some authors (Ramón) being of the opinion that they are nervous; others (Golgi) believe them to have a trophic influence upon the cells. A nerve cell, with its nerve fiber process and the terminal branches of the latter, forms $a$ nerve unit or 'neuron' of Waldeyer. The nervous system is made up of an immense number of those independent units, communicating with and influencing one another by contact' $[9,12]$.

Flatau took a clear stance for neuronism in a subsequent review [47]. He further provided experimental data for the unity of the neuron using the Nissl method, by cutting the oculomotor nerve and detecting secondary changes in the oculomotor nucleus [48]. Fully comprehending the technical basis of brain fixation procedures [49], staining methods [50, 51] and the caprices of silver impregnation [52], Flatau analyzed secondary degeneration after limb amputation in rodents, rabbits and dogs, as well as the effects of toxins, by using the Golgi and Marchi methods [16, 17, 53, 54]. mented the phenomenon of nuclear rotation in neurons [34]. Moreover, in his 1895 Project for a Scientific Psychology [6], Freud proposed the term Contactschranke ('contact barriers') to denote what Charles S. Sherrington (1857-1952) would term 'synapses' 2 years later at the suggestion of the Euripides scholar Arthur W. Verrall (18511912) of Trinity College [35]. The actual visualization of such 'barriers' and definite proof of the neuron theory would be established half a century later by means of the electron microscope $[33,36]$.

The value of Flatau's atlas reaches beyond gross morphology. It firmly supports Ramón y Cajal's neuronismo. Flatau had joined the Anatomical Institute only 2 years after Waldeyer, his director, had introduced the term neuron to denote the nerve or ganglion cell [37]. The word

References
1 Flatau E: Supplement zur ersten Auflage vom Atlas des menschlichen Gehirns und des Faserverlaufes. II. Mikroskopischer Theil. Berlin, Karger, 1899.

-2 Triarhou LC, del Cerro M: Freud's contribution to neuroanatomy. Arch Neurol 1985;42: 282-287.

3 Freud S: Zur Auffassung der Aphasien - Eine kritische Studie. Leipzig-Wien, Franz Deuticke, 1891.

4 Freud S: Literarische Anzeigen - Anleitung beim Studium des Baues der nervösen Centralorgane im gesunden und kranken Zustande. Von Dr H Obersteiner. Wiener Med Wochenschr 1887;37:1642-1644.

5 Freud S: Kritische Besprechungen und literarische Anzeigen - Atlas des menschlichen Gehirns und des Faserverlaufes. Von Ed Flatau. Int Klin Rundschau 1894;8:11311132 . 
6 Freud S: The Standard Edition of the Complete Psychological Works, vol I (1886-1899): Pre-Psycho-Analytic Publications and Unpublished Drafts (transl. by J Strachey and A Freud). London, Hogarth Press/Institute of Psycho-Analysis, 1966.

7 Simchowicz T: Edward Flatau. Schweiz Arch Neurol Psychiatr 1933;31:165-168.

8 Triarhou LC: Edward Flatau (1868-1932). J Neurol 2007;254:685-686.

9 Flatau E: Atlas des menschlichen Gehirns und des Faserverlaufes. Berlin, Karger, 1894.

10 Retzius G: Das Menschenhirn - Studien in der makroskopischen Morphologie. Stockholm, Königliche Buchdruckerei P Norstedt \& Söner, 1896.

11 Flatau E: Über die photographischen Aufnahmen der frischen anatomischen Präparate, speziell des Gehirns. Int Med Photogr Monatsschr 1895;2:97-102.

12 Flatau E: Atlas of the Human Brain and the Course of the Nerve-Fibres (transl. by W Nathan and JH Carslaw). Berlin, Karger/ Glasgow, Bauermeister, 1894.

13 Flatau E: Atlas des menschlichen Gehirns und des Faserverlaufes, zweite wesentlich vermehrte und verbesserte Auflage. Berlin, Karger, 1899.

14 Flatau E: Das Gesetz der excentrischen Lagerung der langen Bahnen im Rückenmark. Z Klin Med (Berl) 1897;33:55-152.

15 Flatau E, Jacobsohn L: Handbuch der Anatomie und Vergleichenden Anatomie des Centralnervensystems der Säugetiere. Berlin, Karger, 1899.

16 Flatau E: Degenerazioni secondarie del midollo spinale; in Flatau E, Jacobsohn L, Minor L (eds): Manuale di Anatomia Patologica del Sistema Nervoso, vol 2 (trad. del E Morandi). Torino, Unione Tipografico-Editrice Torinese, 1909, pp 885-920.

17 Flatau E: Anatomia patologica del tetano; in Flatau E, Jacobsohn L, Minor L (eds): Manuale di Anatomia Patologica del Sistema Nervoso, vol 2 (trad. del E Morandi). Torino, Unione Tipografico-Editrice Torinese, 1909, pp 1205-1217.

18 Eisenberg U: Vom 'Nervenplexus' zur 'Seelenkraft' - Werk und Schicksal des Berliner Neurologen Louis Jacobsohn-Lask (1863-1940). Frankfurt am Main, Peter Lang, 2005.

19 Richter J: Ulrike Eisenberg - Vom 'Nervenplexus' zur 'Seelenkraft' (book review). J Hist Neurosci 2007;16:225-227.

20 Luys J: Iconographie photographique des centres nerveux: atlas de soixante-dix photographies avec soixante-cinq chémas lithographiés. Paris, Baillière, 1873.
21 Luys J: Recherches sur le système nerveux cérébro-spinal: sa structure, ses fonctions et ses maladies; accompagné d'un atlas de 40 planches. Paris, Baillière, 1865.

22 Brissaud É: Anatomie du cerveau de l'homme: morphologie des hémisphères cérébraux, ou cerveau proprement dit; atlas et texte. Paris, Masson, 1893

23 Jakob C: Atlas des gesunden und kranken Nervensystems nebst Grundriss der Anatomie, Pathologie und Therapie desselben. München, Lehmann, 1895.

24 Strümpell A, Jakob C: Neurologische Wandtafeln (Icones Neurologicae) zum Gebrauche beim klinischen, anatomischen und physiologischen Unterricht. München, Lehmann, 1897

25 de Rijcke S: Light tries the expert eye: the introduction of photography in nineteenthcentury macroscopic neuroanatomy. J Hist Neurosci 2008;17:349-366.

26 Koskinas GN: Cytoarchitectonics of the human cerebral cortex. Proc Athens Med Soc 1926;92:44-48.

27 Parent A, Parent M, Leroux-Hugon V: Jules Bernard Luys: a singular figure of 19th century neurology. Can J Neurol Sci 2002;29: 282-288.

28 Walusinski O: Jacques Poirier - Édouard Brissaud, un neurologue d'exception dans und famille d'artistes (book review). Eur Neurol 2010;64:192.

29 von Waldeyer-Hartz W: Nachruf Gustaf Retzius, mit einem Bildnis. Anat Anz 1920; 52:261-268

30 Pearce JMS: Fragments of Neurological History. London, Imperial College Press, 2003.

31 Triarhou LC: Exploring the mind with a microscope: Freud's beginnings in neurobiology. Hellenic J Psychol 2009;6:1-13.

32 Køppe S: The psychology of the neuron: Freud, Cajal and Golgi. Scand J Psychol 1983; 24:1-12.

33 Shepherd GM: Foundations of the Neuron Doctrine. New York, Oxford University Press, 1991.

34 Triarhou LC, del Cerro M: The histologist Sigmund Freud and the biology of intracellular motility. Biol Cell 1987;61:111-114.

35 Shepherd GM, Erulkar SD: Centenary of the synapse: from Sherrington to the molecular biology of the synapse and beyond. Trends Neurosci 1997;20:385-392.

36 Van der Loos H: The history of the neuron; in Hydén $\mathrm{H}$ (ed): The Neuron. Amsterdam, Elsevier, 1967, pp 1-47.

37 Waldeyer HWG: Über einige neuere Forschungen im Gebiete der Anatomie des Centralnervensystems. Dtsch Med Wochenschr 1891; 17: 1213-1218,1244-1246,12871289,1331-1332,1352-1356.
38 Ochs S: A History of Nerve Functions - From Animal Spirits to Molecular Mechanisms. Cambridge, Cambridge University Press, 2004.

39 Ramón y Cajal S: Die histogenetischen Beweise der Neuronentheorie von His und Forel. Anat Anz (Jena) 1907;30:113-144.

40 Ramón y Cajal S: Neuron Theory or Reticular Theory? Objective Evidence of the Anatomical Unity of Nerve Cells (transl. by M Ubeda Purkiss and CA Fox). Madrid, Consejo Superior de Investigaciones Científicas - Instituto Ramón y Cajal, 1954.

41 Ramón y Cajal S: The Neuron and the Glial Cell (transl. and ed. by J de la Torre and WC Gibson). Springfield, Thomas, 1984.

42 von Lenhossék M: Der Feinere Bau des Nervensystems im Lichte Neuester Forschungen. Berlin, Fischer's Medicinische Buchhandlung H Kornfeld, 1893.

43 McHenry LC: Garrison's History of Neurology. Springfield, Thomas, 1969

44 Meyer A: Historical Aspects of Cerebral Anatomy. London, Oxford University Press, 1971.

45 Retzius G: Punktsubstanz, 'nervöses Grau' und Neuronenlehre. Biol Untersuch N Folge (Stockholm-Jena) 1905;12:1-19.

46 Larsell O: Gustaf Magnus Retzius (18421919); in Haymaker W, Baer KA (eds): The Founders of Neurology. Springfield, Thomas, 1953 , pp 83-86.

47 Flatau E: Ueber die Neuronenlehre. Z Klin Med (Berl) 1895;28:51-65.

48 Flatau E: Einige Betrachtungen über die Neuronenlehre im Anschluss an frühzeitige, experimentell erzeugte Veränderungen der Zellen des Oculomotoriuskerns. Fortschr Med (Berl) 1896;16:210-225.

49 Flatau E: Beitrag zur technischen Bearbeitung des Centralnervensystems. Anat Anz (Jena) 1897;13:323-329.

50 Flatau E: Ueber Färbung von Nervenpräparaten. Dtsch Med Wochenschr 1895; 21:212-214.

51 Pollack B: Die Färbetechnik des Nervensystems, zweite, vermehrte und verbesserte Auflage. Berlin, Karger, 1898.

52 Flatau E: Ueber die zweckmässige Anwendung der Golgi'schen Sublimatmethode für die Untersuchung des Gehirns des erwachsenen Menschen. Arch Mikrosk Anat (Bonn) 1895;45:158-162.

53 Goldscheider A, Flatau E: Ueber die Pathologie der Nervenzellen. Arch Psychiatr Nervenkrankh 1897;30:309-312.

54 Goldscheider A, Flatau E: Normale und pathologische Anatomie der Nervenzellen auf Grund der neueren Forschungen. Berlin, Fischer's Medicinische Buchhandlung $\mathrm{H}$. Kornfeld, 1898. 